\title{
Preliminary Study on the Correlations Between Oxytocin Levels and Irritable Bowel Syndrome in Patients with Depression
}

\author{
RALUCA GAVRIL'1, LUMINITA HRITCU2*, MANUELA PADURARIU1, ALIN CIOBICA $3,4,5$, CRISTINA HORHOGEA ${ }^{2 *}$, \\ GABRIELA STEFANESCU ${ }^{1,6}$, MIHAELA CLAUDIA SPATARU ${ }^{2}$, CRINA STRAULEA ${ }^{7}$, CRISTINEL STEFANESCU ${ }^{1}$ \\ ${ }^{1}$ Grigore T. Popa University of Medicine and Pharmacy, 16 Universitatii Str., 700115, Iasi, Romania \\ ${ }^{2}$ Ion Ionescu de la Brad University of Agricultural Science and Veterinary Medicine, 3 Sadoveanu Alley, 700490, Iasi, Romania \\ ${ }^{3}$ Department of Research, Faculty of Biology, Alexandru Ioan Cuza University, 11 Carol I Blvd., 700506, Iasi, Romania \\ ${ }^{4}$ Academy of Romanian Scientists, 54 Splaiul Independentei, 050094, Bucharest, Romania \\ ${ }^{5}$ Center of Biomedical Research, Romanian Academy, 8 Carol I Blvd., 700505, Iasi, Romania \\ ${ }^{6}$ Institute of Gastroenterology \& Hepatology, 1 Independentei Blvd., 700111, lasi, Romania \\ ${ }^{7}$ Socola Hospital Iasi, 36 Bucium Str., 700282, Iasi, Romania
}

\begin{abstract}
Lately there are increased evidences that oxytocin may be an important mediator in several psychiatric disorders including depression and anxiety. Oxytocin system seems to be linked with several neurotransmitters important in psychiatric disorder, butalso with the hypothalamic-pituitary-adrenal (HPA) axis and is also a key factor in stress regulation mechanisms. Considering the oxytocin receptor pattern of distribution both central and peripherally and the growing data concerning the disbalance of oxytocin in psychiatric disorders we may speculate that oxytocin system may be at the core of psychosomatic disturbances. Also, recent data brought to attention that oxytocin receptor is distributed throughout gastrointestinal tract. Our hypothesis of the present study was that oxytocin system is disbalanced in irritable bowel syndrome considering also the psychological component of this digestive disorder. We preliminary report here a significant decrease of serum oxytocin levels in patients with major depression disorder and irritable bowel syndrome, as compared with those with major depression disorder alone.
\end{abstract}

Keywords: oxytocin, serum, depression, irritable bowel syndrome

Lately there is an increased awareness on the possible relevance of oxytocin as an important mediator in several psychiatric disorders including anxiety, autism, schizophrenia and depression as our group extensively reviewed or demonstrated lately [1-7].

Oxytocin system seems to be linked with several neurotransmitters important in psychiatric disorder [8], but also with hypothalamic-pituitary-adrenal (HPA) axis, being a key factor in stress regulation mechanisms [9]. Considering the oxytocin receptor pattern of distribution both central and peripherally and the growing data concerning the misbalance of oxytocin in psychiatric disorders we could speculate that oxytocin system may be at the core of psychosomatic disturbances.

Also, recent data demonstrated that oxytocin receptor is distributed throughout gastrointestinal tract, although different studies showed both stimulatory or inhibitory effects of oxytocin on gut [10].

In this way, it was demonstrated even from 1996 in a Gut journal report by Louvel group that oxytocin increases thresholds of colonic visceral perception in patients with irritable bowel syndrome [11], as this could have important therapeutical implications since a significantly decreased threshold for visceral sensitivity could be implicated in the pathology of IBS.

Also, 10 years later the Ohlsson group clearly showed that oxytocin is expressed throughout the human gastrointestinal tract in a report published in Regulatory Peptides [10].

In addition, itwas also previously suggested that oxytocin could treat abdominal pain in a mice model [12], as well as the fact that oxytocin could regulate inflammatory processes in the context of modulating the gastrointestinal motility and mucosal maintenance [13].
Thus in the present study we were interested in seeing if oxytocin system is misbalanced in irritable bowel syndrome (IBS - a functional digestive disorder characterized by stool abnormalities, diarrhea or constipation or both form alternating between them over time, accompanied by abdominal pain, bloating or flatulence, without anatomical or structural deficits [14], by considering also the psychological component of this disorder, as all of our selected patients were diagnosed with major depression disorder (MDD), with only part of them having irritable bowel syndrome.

\section{Experimental part \\ Material and methods \\ Samples}

In the present study, we selected patients that were admitted in Socola Psychiatric Hospital with the diagnostic of depression and irritable bowel syndrome. The patients signed an informed consent and were screened to be included in our study and local committee approved the study. Patients with other major psychiatric disorder, patients suffering from other digestive illnesses, with other untreated somatic diseases were excluded from the study. The diagnostic of depression was established following ICD-10 and DSM V criteria and the diagnostic of irritable bowel syndrome met the ROME IV criteria. The patients (total $n=12$ ) were psychometric tested with HAMD scale. A control group was selected that included patients with depression without digestive symptoms $(n=8)$. We collected blood samples from all the patients to test the oxytocin level.

Oxytocin measurement. Serum samples were obtained byvenous blood harvested in red topped tubes; the samples were allowed to clot for $2 \mathrm{~h}$ at room temperature before 
centrifugation for $20 \mathrm{~min}$ at $1000 \times \mathrm{g}$. The supernatant was collected and stored at $-20^{\circ}$ before testing.

The oxytocin was evaluated using a competitive EIA in 96 well plates: Oxytocin ELISA Kit (LSBio LifeSpan Bio Sciences, Inc.) following the manufacturer instructions.

The concentration of oxytocin in the serum samples was evaluated with the use of eight standard solutions with well know oxytocin concentrations in order to generate a standard curve. From the standard stock solution (S1) $(1000 \mathrm{pg} / \mathrm{mL})$ standard dilutions were prepared: $\mathrm{S} 2(500 \mathrm{pg} / \mathrm{mL}), \mathrm{S} 3(250 \mathrm{pg} / \mathrm{mL}), \mathrm{S} 4(125 \mathrm{pg} /$ $\mathrm{mL})$, S5 (62.5 pg/mL), S6 (31.25 pg/mL), S7 (15.63 pg/ $\mathrm{mL})$, S8 (0 pg/mL).

This technique used biotinylated detection antibodies, avidin -horseradish peroxidase conjugate (A-HRP-C) and a specific substrate for the enzyme $\left(3,3^{\prime}, 5,5^{\prime}\right.$ Tetramethylbenzidine (TMB)). This substrate develops a blue color with different intensity in function of the amount of oxytocin in the serum samples. The optical density (OD value) of each well was determined using a microplate reader (Stat Fax 3200 Awareness Technology Inc.) set to $450 \mathrm{~nm}$.

The OD of the serum sample were compared to the OD of the standard curve generated. In competition assay the greater the amount of antigen (oxytocin) in the sample, the lower the color development and optical density reading.

\section{Data analysis}

The conversion of the $O D$ values in $\mathrm{pg} / \mathrm{mL}$ was accomplished using a formula according to the Excel. Then data was statistically analyzed by using Student's t-test (two tailed, unpaired). All results are expressed as mean \pm SE. $p<0.05$ was regarded as statistically significant. The analyses were performed using the Excel program.

\section{Results and discussions}

As mentioned, from the 12 patients were included in the study, 4 patients with major depression and irritable bowel syndrome and 8 patients with depression without irritable bowel syndrome. The age of the patients varied between 43 and 60 years old. The mean age of the study group was $43( \pm 5.77)$ years and the mean age for the control group was $55.2( \pm 4.8)$ years. Our group included both male and female and they were from both urban and rural background.

The mean age for HAMD score was $29.33( \pm 1.15)$ for the study group and $30( \pm 2.64)$ for the control group.

As it can be seen in the figure 1, oxytocin levels were found to be at $242.75( \pm 3.52) \mathrm{pg} / \mathrm{mL}$ in the MDD patients which were also IBS sufferers and at $302.1( \pm 23,6)$ in depressed patients without IBS. Moreover, this decrease of oxytocin levels in depressed patients + IBS vs. patients with depression alone was very statistically significant $(p$ $=0,00006)$, despite the relatively small number of patients selected for this study (fig. 1).

In the present report we preliminary demonstrated a significant decrease of serum oxytocin levels in patients with major depression disorder and irritable bowel syndrome, as compared with those with major depression disorder alone.

In this way, besides being clearly showed previously that oxytocin is expressed in the myenteric and submucous ganglia and nerve fibres of the entire human gastrointestinal tract [10] and the well-known effects of oxytocin in the colonic peristaltism and accelerated gastric emptying [10], the alleviating effects of oxytocin intranasal administration of the discomfort associated with chronic idiopathic

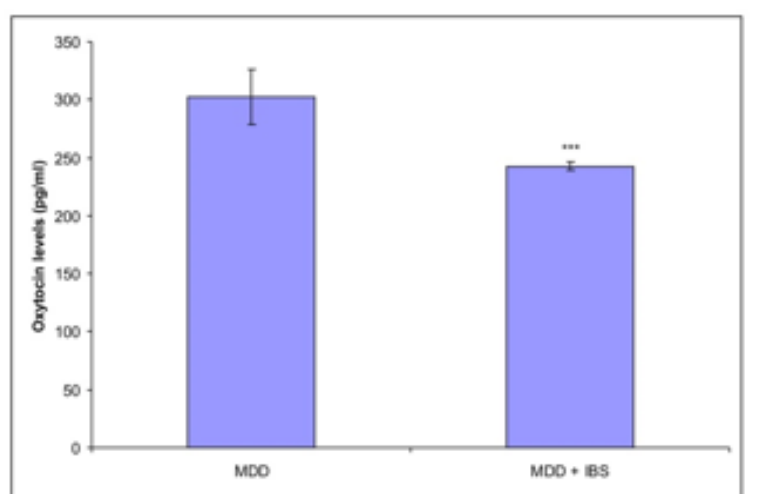

Fig. 1. Oxytocin levels $(\mathrm{pg} / \mathrm{mL})$ in patients with major depression disorder (MDD), as compared with those with major depression disorder and irritable bowel syndrome (IBS). ${ }^{* * *} p=0,00006$ vs. MDD alone group

constipation in IBS $[11,12]$ or the gastric emptying modulation from the diabetic patients with gastroparesis [15] as cited in [13], to our best of knowledge there are no previous studies with a set up based on the comparison of patients with depression + IBS vs. depression alone. In fact, it is generally accepted that the clear effects of oxytocin in the human gastrointestinal tract are yet to be understand.

As mentioned, our present report suggested a decrease in the oxytocin levels in patients with major depression disorder and irritable bowel syndrome, when compared with those having depression only. This could be explained by depleted levels of oxytocin as a result of the depressive pathology, considering the protective effects of oxytocin, which were previously reported [10-13]. Or thinking the other way around, these patients could have their oxytocin levels depleted, which is making them more prone to a depressive state.

In the same way, it was also previously showed that blocking the specific oxytocin receptors in some mice genetic models will result in a significant increase in the number of enteric neurons [13].

Moreover, recently another group reported that central oxytocin could mediate the adaptation mechanism of colonic transit as a result of chronic homotypic, but not heterotypic stress in rats models [16].

Also, mecanistically these results can be explained perhaps by the lack of a so-called social interaction and affiliation, which are sometimes associated with the pathophysiology of depression [17].

In addition, our result reported here can mecanistically relate to the nociceptive processes, since oxytocin is a widely accepted analgesic $[5,18,19]$, although there is a clear lack of evidences on the clear mechanisms explaining the nociceptive effects of oxytocin [12].

Also, other authors are mentioning in the mechanisms context the correlations that exist between oxytocin and nitric oxide [20, 21].

As mentioned above, some of the gastrointestinal effects of oxytocin were also correlated with some antiinflammation effects, since it was showed that itcan affect aspects such as gastrointestinal motility, inflammation, macromolecular permeability, and mucosal maintenance in mice models, basically protecting and slowing gut's activity [13]. Thus, by using specific oxytocin receptors kockout mice, it was demonstrated that the intestinal transit was faster than in the wild type mice, with some effects also in the stool mass and water content (e.g. both increased in specific oxytocin receptors knockout mice) [13]. 
In addition, some other groups demonstrated that oxytocin could also exert protective effects against factors such as acetic acid-induced injuries or oxidative damage $[22,23]$ as cited by [13]. This could be also related to the previous described antioxidant effects of oxytocin [24-26], in the context of the oxidative metabolism implications for most of the neuropsychiatric and gastrointesinal disorders [27-30] and the correlations between these two groups of disorders [14].

As also mentioned above, these factors could exertsome kind of therapeutical interest in the context of oxytocin implications in IBS, since it was showed by using five doses of oxytocin $(10,20,30$, and $50 \mathrm{mU} / \mathrm{min}$-but it only works for doses equal or to greater than $20 \mathrm{mU} / \mathrm{min}$ ) that it increases thresholds of colonic visceral perception (e.g. by analyzing first sensation and pain threshold) in patients with irritable bowel syndrome [11], being known that a very decreased threshold for visceral sensitivity is a factor of IBS complex pathological presentation [11]. Interestingly enough, the same group also reported similar effects for somatostatin analogues [31].

Also regarding the therapeutical context we can mention here a recent study published by the Nature group in which Araujo et al. group showed in 2013 some protective effects of oxytocin analogues selenoether in alleviating a rodent model of abdominal pain [12]. Thus, the aforementioned group reported that oxytocin specific receptors are upregulated in the nociceptors of the colon, with the aforementioned selenoether oxytocin analogues inhibiting nociceptors from the colon in a mice model of abdominal pain [12].

Regarding the limitations of our study we can mention, of course, the reduced number of patients we used, as this is a preliminary study on this matter and, as mentioned above, a fist attempt to understand the correlations between oxytocin levels and irritable bowel syndrome in patients with depression.

\section{Conclusions}

We preliminary report here a significant decrease of serum oxytocin levels in patients with major depression disorder and irritable bowel syndrome, as compared with those with major depression disorder alone.

Acknowledgments: PM and CA are supported by a research great for Young Teams offered by UEFISCDI Romania, no. PN-III-P1-1.1-TE-20161210, contract no. 58 from 02/05/2018, called Complex study regarding the interactions between oxidative stress, inflammation and neurological manifestations in the pathophysiology of irritable bowel syndrome (animal models and human patients).

\section{References}

1.CIOBICA, A., BALMUS, I. M., PADURARIU, M., Acta Endocrinologica, 12, no. 1, 2016, p. 65, doi: 10.4183/aeb.2017.60.

2.PADURARIU, M., PREPELITA, R., CIOBICA, A., DOBRIN, R., TIMOFTE, D., STEFANESCU, C., CHIRITA, R., Neurophysiology, 48, no. 4, 2016, p. 312 doi: 10.1016/j.yhbeh.2017.06.001.

3.PADURARIU M., CIOBICA A., Nobel Medicus, 13, no. 3, 2017, p. 5. 4.VARGÁNÉ, K.A., CIOBICA A., TOPAL, J., Hormones and Behavior, 28, no. 94, 2017, p. 40.

5.ANTIOCH, I., ABABEI, D., LEFTER, R., CIOBICA, A., HONCERIU, C., BILD, V., Rev.Chim.(Bucharest), 68, no. 9, 2017, p. 2028.
6.BALMUS, I.M., LEFTER, R., CIOBICA, A., ANTIOCH, I., ABABEI, D., DOBRIN, R., Psychiatr Danub, 30, no. 1, 2018, p. 9, doi: 10.24869/ psyd.2018.91.

7.PADURARIU, M., BALMUUS, M., CIOBICA, A., LEFTER, R., COJOCARU, S., ANTIOCH, I., FOYET, H., DOBRIN, R., ABABEI, D., BILD, V., Farmacia, 66, no. 3, 2018, p. 421.

8.BARIBEAU, D.A., ANAGNOSTOU, E., Front Neurosci., 9, 2015, p. 335. doi:10.3389/fnins.2015.00335.

9.NEUMANN, I.D., KRÖMER, S.A., TOSCHI, N., EBNER, K., Regul Pept., 96, no. 1-2, 2000, p. 31.

10.OHLSSON, B., TRUEDSSON, M., DJERF, P., SUNDLER, F., Regul Pept., 135, no. 1-2, 2006, p.7.

11.LOUVEL, D., DELVAUX, M., FELEZ, A., FIORAMONTI, J., BUENO, L., LAZORTHES, Y., Gut., 39, no. 5, 1996, p.741, DOI:10.1136/gut.39.5.741. 12.DE ARAUJ O, A.D., MOBLI, M., CASTRO, J., HARRINGTON, A.M., VETTER, I., DEKAN, Z., MUTTENTHALER, M., WAN, J., LEWIS, R.J., KING, G.F., BRIERLEY, S.M., ALEW OOD, P.F., Nat Commun., 5, 2014, p. 3165. DOI:10.1038/ncomms4165.

13.WELCH, M.G., MARGOLIS, K.G., LI, Z., GERSHON, M.D., Am. J. Physiol. Gastrointest Liver Physiol., 307, no. 8, 2014, p. 848. doi: 10.1152/ajpgi.00176.2014.

14.LEFTER, R., CIOBICA, A., QUEEN, S., COMPAORE, M., TIENDREBEOGO, M., STANCIU, C., TRIFAN, A., Neurophysiology, 50, no. 4, 2018, p. 266.

15.BORG, J., OHLSSON, B., BMC Res Notes, 5, 2012, p. 148, doi: 10.1186/1756-0500-5-148.

16.SAZU, Y., CERJAK, D., BABYGIRIJA, R., BULBUL, M., LUDWIG, K.A., TAKAHASHI, T., Gastroenterology, 140, no. 5, 2011, p. 465,

DOI: https://doi.org/10.1016/S0016-5085(11)61912-4.

17.TEO, A.R., CHOI, H., VALENSTEIN, M., PLoS One., 8, no. 4, 2013, p. 62396, doi:10.1371/journal.pone.0062396.

18.PADURARIU, M, ANTIOCH, I., CIOBICA, A., LEFTER, R., SIMION, L., Rev.Chim.(Bucharest), 68, no. 8, 2017, p. 1879

19.PALOYELIS, Y., KRAHÉ, C., MALTEZOS, S., WILLIAMS, S.C., HOWARD, M.A., FOTOPOULOU, A., J Neuroendocrinol., 28, no. 4, 2016, doi: 10.1111/jne.12347.

20.MELIS, M.R., SUCCU, S., IANNUCCI, U., ARGIOLAS, A., Regul Pept., 69, no. 2, 1997, p. 105.

21.BILD, W., CIOBICA, A., PADURARIU, M., BILD, V., J ournal of Physiology and Biochemistry, 69, no. 1, 2013, p. 147.

22.ISERI, S.O., GEDIK, I.E., ERZIK, C., USLU, B., ARBAK, S., GEDIK, N., YEGEN, B.C., Burns, 34, 2007, p. 361, DOI: 10.1016/j.burns.2007.03.022. 23.ISERI, S.O., SENER, G., SAGLAM, B., GEDIK, N., ERCAN, F., YEGEN, B.C., Peptides, 26, 2005, p. 483 DOI:10.1016/j.peptides.2004.10.005.

24.BALMUS, I. M., CIOBICA, A., STOICA, B., LEFTER, R., COJOCARU, S.I., REZNIKOV, A., Neurophysiology, 51, no. 1, 2019, p. 18, DOI 10.1007/ s11062-019-09785-w.

25.HONCERIU, C., CIOBICA, A., STOICA, B., CHIRAZI, M., PADURARIU, M., Rev.Chim.(Bucharest), 67, no. 11, 2016, p. 2246.

26.WANG, Y., ZHAO, S., LIU, X., ZHENG, Y., LI, L., MENG, S., Biomed Pharmacother., 107, 2018, p. 262 doi: 10.1016/j.biopha.2018.07.148. 27.CIOBICA, A., HRITCU, L., ARTENIE, V., STOICA, B., BILD, V., Acta Endocrinologica, 5, 2009, p. 425, doi: 10.4183/aeb.2009.425.

28.FOYET, H.S., ABAIISSOU, H.H., WADO, E., ACHA, E.A., ALIN, C., BMC Complement. Altern. Med., 15, 2015, p. 333. doi:10.1186/s12906015-0864-4.

29.CIOBICA, A., HRITCU, L., NASTASA, V., PADURARIU, M., BILD, V., J. Med. Biochem., 30, no. 2, 2011, p. 109, DOI: https://doi.org/10.2478/ v10011-011-0009-3

30.CIOBICA, A., PADURARIU, M., HRITCU, L., Psychiatr. Danub, 24, no. 2, 2012, p. 194.

31.DELVAUX, M., LOUVEL, D., SCHERRER, B., FRAITAG, B., FREXINOS, J., Gastroenterology, 108, 1995, p. 590.

Manuscript received: 19.12 .2018 